\title{
International Journal of Research SCIENCE \& MANAgEMENT ASSOCIATION BETWEEN CLUSTER OF DIFFERENTIATION 4 COUNT AND THE CLINICAL OUTCOMES OF CEREBRAL TOXOPLASMOSIS IN POSITIVE HIV PATIENTS
}

\author{
Utami Tarigan**1, Kiking Ritarwan ${ }^{2} \&$ Irina Kemala Nasution ${ }^{2}$ \\ ${ }^{1}$ Resident Department of Neurology, Faculty of Medicine, University of North Sumatera \\ ${ }^{2}$ Department of Neurology Staff, Faculty of Medicine, University of North Sumatera
}

DOI: https://doi.org/10.29121/ijrsm.v7.i8.2020.7

Keywords: CD4, HIV, Karnofsky Scale, cerebral toxoplasmosis.

\begin{abstract}
Background: About $30 \%$ to $40 \%$ of HIV patients ultimately will develop cerebral toxoplasmosis.
\end{abstract}

Objectives: To determine the relationship between CD4 count and clinical outcomes of cerebral toxoplasmosis in HIV positive patients.

Methods: This study uses a cross-sectional design. Sampling was conducted at the Integrated Inpatient Room at H. Adam Malik Hospital Medan. The study sample was taken as many as 31 consecutive subjects. CD4 count and KPS (Karnofsky performance score) examinations were performed. CD4 is calculated using the flow cytometry method. The Karnofsky scale is measured to determine the patient's performance status. Data analysis using fisher's exact test.

Results: The demographic characteristics of the research subjects were male (93,5\%), age range 34,38 \pm 7,67 years, marital status $(64,5 \%)$, high school education level $(74,2 \%)$, and entrepreneurial work (64,5\%). CD4 count $<100$ were obtained in $67.7 \%$ of subjects with a median value of 25 (2-480). As many as $77.4 \%$ of subjects had a karnofsky scale value of $\leq 70$ with a median value of $50(0-80)$. There is a significant relationship between CD4 count and clinical outcomes of cerebral toxoplasmosis in HIV positive patients, while CD4 $<100$ cells / $\mu \mathrm{L}$ can increase clinical risk with a Karnofsky Performance Scale (KPS) score $\leq 70$ to 1.8 times greater $(\mathrm{p}=0.02$ and $\mathrm{PR}$ $=1.8$ and Confidence Interval 95\% $=0,95-3,41)$.

Conclusions: There is a significant relationship between CD4 count and clinical outcomes of cerebral toxoplasmosis in HIV positive patients.

\section{Introduction}

In HIV / AIDS patients, there is a state of immune deficiency caused by progressive quantitative and qualitative deficiencies of $\mathrm{T}$ lymphocytes ( $\mathrm{T}$ helper). This subset of $\mathrm{T}$ cells is described phenotypically by expression on the cell surface of CD4 (Cluster of Differentiation 4) molecules that act as primary receptors for HIV. In HIV patients CD4 cell drops below the critical level $(\mathrm{CD} 4<200 / \mathrm{ul})$ so that the patient becomes very vulnerable to opportunistic infections. ${ }^{1}$

The most common manifestation of HIV is encephalitis. Encephalitis occurs in about $80 \%$ of cases. $^{1}$ Toxoplasmosis encephalitis can occur in 30 to $40 \%$ of patients who do not receive toxoplasmosis prophylaxis in HIV. ${ }^{2}$ Cerebral toxoplasmosis is one of the cases of neurological emergencies in HIV and is an indicator of a poor prognosis in people with AIDS and contributes $23 \%$ of AIDS patient mortality. CD4 is a type of white blood cell or lymphocyte that plays a role in the immune system. ${ }^{3}$

A decrease in progressive CD4 cell count is associated with an increase in clinical complications. ${ }^{4}$ The results of the study by Sow et al (2019) stated that cerebral toxoplasmosis is associated with high levels of morbidity and mortality in the Infectious Disease Unit at Donka National Hospital. CD4 levels $<200$ cells / ml, independently associated with death. Patients with CD4 cell counts $<200$ cells $/ \mathrm{mm}^{3}$ at the start of anti-retroviral therapy had a 19 times greater risk than patients with CD4 levels $\geq 200$ cells $/ \mathrm{mm}^{3} .5$ 


\section{International Journal of Research SCIEnCE \& MANagement}

\section{Method}

\section{Study sample}

The study sample was taken from cerebral toxoplasmosis patients with HIV positive in Adam Malik General Hospital Medan with consecutive sampling techniques. The research subjects consisted of 31 cerebral toxoplasmosis patients with HIV positive and willing to take part in the study by signing a research informed consent sheet.

\section{Study design}

This study is a cross-sectional design without treatment. Presumptive diagnosis for cerebral toxoplasmosis is based on the CDC (Centers for Disease Control and Prevention) criteria, 1993 based on clinical symptoms, IgG examination of T. gondii, radiological features (CT scan or MRI scan of the head), in addition the diagnosis can also be based on the presence clinical response to treatment of toxoplasmosis.

\section{Statistical analysis}

Data from the research were analyzed statistically using the SPSS computer program (Statistical Product and Science Service) version 22.0. To analyze the relationship between research variable, in the case to determine the relationship between Cluster of Differentiation 4 Levels and the Clinical Outcomes with fisher test.

\section{Result}

Cerebral toxoplasmosis patients with HIV positive at H. Adam Malik Hospital Medan in March until June 2020, there were 31 patients who participated in the study.

\begin{tabular}{lcc}
\multicolumn{3}{c}{ Table1. Demographic Characteristic of Research Subject $(\mathbf{n}=\mathbf{3 1})$} \\
\hline Characteristics & $\begin{array}{c}\text { Frequency } \\
\mathrm{n}=71\end{array}$ & $\begin{array}{c}\text { Percentage } \\
\%\end{array}$ \\
\hline Age average \pm SD (years) & $34,38 \pm 7,67$ & \\
$25-<38$ years old & 22 & 71,0 \\
$38-<51$ years old & 7 & 22,6 \\
$51-63$ years old & 2 & 6,5 \\
Sex & & \\
Male & 29 & 93,5 \\
Female & 2 & 6,5 \\
Marital status & 20 & \\
Married & 11 & 64,5 \\
Single & & 35,5 \\
& & \\
Education & 1 & 3,2 \\
Primary School & 3 & 9,7 \\
Junior High School & 23 & 74,2 \\
Senior High School & 1 & 3,2 \\
Diploma & 3 & 9,7 \\
Bachelor & & \\
Job & 20 & 64,5 \\
Enterpreneur & 2 & 6,5 \\
Part time worker & 1 & 3,2 \\
Civil Servants & 7 & 22,6 \\
Private Employees & 1 & 3,2 \\
College student & &
\end{tabular}

Based on the characteristics of 31 research subjects, the age of all research subjects had a mean of 34,38 $\pm 7,67$ years with the most age group were $25-<38$ years. There were 29 men (93.5\%) and 2 women (6.5\%). The marital status of the most research subjects is 20 subjects $(64.5 \%)$ was married. The education level of the most respondents was Senior High School (SMA) with a total of 23 subjects (74.2\%). The most occupational subjects are entrepreneur as many as 20 subjects $(64,5 \%)$. General description of the subject of this study is shown in the table 1. 


\section{International Journal of Research SCIEnCE \& MANagement}

Based on the characteristics of CD4 levels in 31 study subjects who participated in this study, it was found that the overall CD4 cell count had median values of 25 cells / $\mu \mathrm{L}(2-480)$ were divided into $<100$ cells / $\mu \mathrm{L}$ by 21 subjects $(67.7 \%)$ and $\geq 100$ cells / $\mu \mathrm{L}$ by 10 subjects $(32.3 \%)$. This can be seen in table 2 below.

Table 2. Characteristics of CD4 levels

\begin{tabular}{lccc}
\hline \multicolumn{5}{c}{ Table 2. Characteristics of CD4 levels } \\
\hline Characteristic of CD4 & $\begin{array}{c}\text { Median } \\
(\text { minimum- } \\
\text { maximum) }\end{array}$ & $\mathrm{n}$ & $\begin{array}{c}\text { Percentage } \\
(\%)\end{array}$ \\
\hline $\mathrm{CD} 4$ & $25(2-480)$ & \\
\hline$\quad<100 \mathrm{cell} / \mu \mathrm{L}$ & & 21 & 67,7 \\
$-\quad \geq 100 \mathrm{cell} / \mu \mathrm{L}$ & & 10 & 32,3
\end{tabular}

Descriptive analysis of clinical outcome characteristics in this study was measured using the Karnofsky Performance Scale (KPS). Based on the characteristics of KPS, the results obtained that the overall KPS has a median value of $50(0-80)$ which is divided into $\leq 70$ as many as 24 subjects $(77.4 \%)$ and $>70$ as many as 7 subjects $(22.6 \%)$. This can be seen in table 3 below.

Table 3. Characteristic of clinical outcomes

\begin{tabular}{|c|c|c|c|}
\hline $\begin{array}{l}\text { Characteristic of clinical } \\
\text { outcomes }\end{array}$ & $\begin{array}{l}\text { Median } \\
\text { (minimum- } \\
\text { maximum) }\end{array}$ & $\mathrm{n}$ & Percentage (\%) \\
\hline $\begin{array}{ll}\text { Karnofsky } & \text { Performance } \\
\text { Scale (KPS) } & \end{array}$ & $50(0-80)$ & & \\
\hline - $\leq 70$ & & 24 & 77,4 \\
\hline - $\quad>70$ & & 7 & 22,6 \\
\hline
\end{tabular}

In this study the statistical analysis used was the fisher's exact test. The results showed that subjects with a CD $<$ 100 cells / $\mu \mathrm{L}$ had a KPS score $\leq 70$ of 19 subjects $(90.5 \%)$ and KPS $>70$ of 2 subjects $(9.5 \%)$, while the group with a category of $\geq 100$ cells / $\mu \mathrm{L}$ has a KPS score $\leq 70$ of 5 subjects $(50 \%)$ and KPS $>70$ of 5 subjects $(50 \%)$, so it can be concluded that the percentage of KPS $\leq 70$ is higher in the $<100$ cell $/ \mu \mathrm{L}$ group than that of $\geq 100$ cells / $\mu \mathrm{L}$.

Based on the fisher's exact test, it was found that there was a significant relationship between CD4 and clinical outcomes of cerebral toxoplasmosis in HIV positive patients with a $p$ value of 0.02 and a prevalence ratio (PR) of $1.8(\mathrm{CI} 95 \%=0,95-3,41)$ where the CD4 $<100$ cells $/ \mu \mathrm{L}$ could increase the risk of outcomes clinically with a Karnofsky Performance Scale (KPS) score of $\leq 70$ as much as 1.8 times greater. This can be seen in table 4 below.

Table 4. Relationship between CD4 and clinical outcomes

\begin{tabular}{|c|c|c|c|c|c|}
\hline \multirow{2}{*}{ Category of CD4 } & \multicolumn{2}{|c|}{ Category of KPS } & \multirow[t]{2}{*}{$p$} & \multirow[t]{2}{*}{ PR } & \multirow[t]{2}{*}{ CI 95\% } \\
\hline & $\begin{array}{l}\leq 70 \\
\mathrm{n}(\%)\end{array}$ & $\begin{array}{l}>70 \\
n(\%)\end{array}$ & & & \\
\hline$<100 \mathrm{se} / \mu \mathrm{L}$ & $\begin{array}{c}19 \\
(90,5 \%)\end{array}$ & $\begin{array}{c}2 \\
(9,5 \%)\end{array}$ & & & \\
\hline$\geq 100 \mathrm{sel} / \mu \mathrm{L}$ & $\begin{array}{c}5 \\
(50 \%)\end{array}$ & $\begin{array}{c}5 \\
(50 \%)\end{array}$ & 0,02 & 1,8 & $0,95-3,41$ \\
\hline
\end{tabular}




\section{International Journal of Research SCIEnCE \& MANagement}

\section{Discussion}

The mean age characteristics of intracranial tumor patients in this study were $34.38 \pm 7.67$ years with the most age range at age $25-<38$ years, which was 22 subjects $(71 \%)$. The results of this study were relevant to previous studies conducted by Indrayani (2011) who reported the age characteristics of cerebral toxoplasmosis in HIV positive patients, which was most experienced at mean age $34 \pm 9$ years. ${ }^{6}$ The mean age in this study approached the study of Luma et al (2013) which stated that the mean age of cerebral toxoplasmosis in HIV positive patients was $36.9 \pm 14.1$ years. ${ }^{7}$ The description of new HIV positive cases according to age group shows that the majority of new cases occur in the age of 30-39 years. This age group belongs to the sexually active productive age group and includes an age group that is vulnerable to injecting drug use. ${ }^{8}$

In this study, the characteristics of cerebral toxoplasmosis in HIV positive patients were 29 male subjects $(93.5 \%)$. Research conducted by Ismayani et al (2012) who reported toxoplasmosis in HIV positive patients in men (94.3\%) was higher than women (5.7\%). Similar results were also published in the study of Achappa et al (2011) that toxoplasmosis in HIV positive patients was more common in men $(87.9 \%)$ than women (12.1\%). ${ }^{9}$ Report of the Directorate General of PP and PL in 2016, which mentions the most HIV / AIDS sufferers is in the male gender category. ${ }^{10}$ The survey results from the BKKBN also revealed that one commercial sex worker with HIV can transmit a minimum of six men who have sex. ${ }^{11}$

Marital status of cerebral toxoplasmosis in HIV positive patients with the most number of marriages is 20 subjects (64.5\%). The results of this study are relevant to previous studies conducted by Sow et al (2019) at Donka National Hospital, Conakry, Guinea who reported toxoplasmosis in HIV positive patients more in marital status $(65.5 \%)$ compared to unmarried $(25,3 \%)$. ${ }^{5}$ Similar results were also released in the study of Achappa et al (2011), which is more common in 25 marital status subjects (75.7\%) than in unmarried 8 subjects $(24.2 \%) .{ }^{9}$ Married status shows someone who has been actively involved in a sexy and agreed relationship with feelings of dissatisfaction with his partner and then having an affair. This can be a risk factor for HIV / AIDS transmission. ${ }^{12}$

The highest education level of subjects was high school, which was 23 subjects (74.2\%). This is in line with research conducted by Indrayani et al in 2011 mentioning that the highest level of education in their study was high school, which was $72.5 \% .{ }^{13}$ According to Widayanti et al, 2018, high school is included in the secondary education category, where knowledge about health is still lacking at this level of education. ${ }^{14}$

In this study, the CD4 results had a median value of 25 cells / $\mu \mathrm{L}(2-480)$. The results of this study are close to previous studies conducted by Luma et al (2013) who reported a median CD4 value of cerebral toxoplasmosis in HIV positive patients of 41 cells / $\mu \mathrm{L}$ (24-75). ${ }^{7}$ Similar results were reported by Ismayani et al (2012) with a mean CD4 of $47.3 \pm 68.7 .^{15}$ The median CD4 value in this study is also close to compared to research by Achappa et al (2011) which mentions the highest percentage of CD4 cell counts is $<100$ cells / $\mu \mathrm{L}$. $^{9}$ In HIV, clinical manifestations occur when the number of CD4 lymphocytes $<100$ cells $/ \mu \mathrm{L}$. The most common manifestation of HIV is encephalitis. Toxoplasma gondii infection in healthy humans is usually asymptomatic, whereas AIDS patients infected by parasites are often accompanied by toxoplasma encephalitis. ${ }^{16}$ An increase in the frequency of toxoplasma encephalitis has been reported in patients with AIDS, especially in those with CD4 counts $<100$ cells / mL. ${ }^{17}$

Cell-mediated T-cell immunity, macrophages, and Type- 1 cytokine activity (interleukin-12 and gamma INF interferon) are needed to maintain the latent period of chronic T. gondii infection. The production of gamma IL12 and INF is stimulated by CD154 (also known as CD40 ligand). CD154 acts by triggering dendritic cells and macrophages to release IL-12, in turn increasing the production of gamma INF by T-cells. In immunosuppressed HIV infection, opportunistic infections with T. gondii due to CD4 T cell depletion, disruption of IL-12 and gamma INF production and disruption of cytotoxic $\mathrm{T}$ lymphocyte activity. There is a decrease in in vitro production of IL-12, gamma INF, and decreased expression of CD154 in response to T. gondii. ${ }^{1}$

Descriptive analysis of clinical outcome characteristics in this study was measured using the Karnofsky Performance Scale (KPS). The results of KPS have a median value of $50(0-80)$ which is divided into $\leq 70$ by 24 subjects $(77.4 \%)$ and $>70$ as many as 7 subjects $(22.6 \%)$. The results of this study are relevant to those reported by Ismayani et al (2012) that the Karnofsky scale median was $50 .{ }^{15}$ The results of this study were also not much different from the study by Vidal et al (2005) who reported the average Karnofsky scale 60. The Karnofsky scale was less than 70 provides a role as a rush predictor. ${ }^{18}$ 


\section{International Journal of Research SCIEnCE \& MANagement}

Based on the fisher's exact test statistical analysis of 31 subjects, the results show that there is a significant relationship between CD4 and clinical outcomes of cerebral toxoplasmosis in HIV positive patients with a $p$ value of 0.02 and a prevalence ratio (PR) of 1.8 (CI 95\% $=0,95-3,41)$ where the CD4 condition $<100$ cells $/ \mu \mathrm{L}$ could increase the risk of outcomes clinically with a Karnofsky Performance Scale (KPS) score of $\leq 70$ as much as 1.8 times greater. The results of this study are relevant to previous studies conducted by Sow et al (2019) who reported a significant relationship between CD4 cell count and clinical outcome of cerebral toxoplasmosis in HIV positive patients with $\mathrm{p}<0.001 .^{5}$ In a study conducted by Luma et al (2013) also found a significant relationship between low CD4 cell count $(\mathrm{CD} 4<100$ cells $/ \mu \mathrm{L})$ and mortality $(\mathrm{p}<0.001){ }^{7}$

HIV infection causes a reduction in CD4 cells, where in T cell activation is thought to determine the clinical outcome of Toxoplasma gondii infection. ${ }^{19} \mathrm{CD} 4$ lymphocytes are the main target of HIV infection because the virus has an affinity for CD4 surface molecules. CD4 lymphocytes function to coordinate a number of important immunological functions. The loss of this function causes progressive impaired immune response. ${ }^{3}$ In healthy adults, intracellular parasites are controlled by the immune system and remain inactive in the brain, but in patients with AIDS, the immunocompromised state causes reactivation of the T. gondii parasite and develops into toxoplasmosis. Uncontrolled parasitic replication occurs, which causes life-threatening brain damage characterized by brain abscesses and necrotic areas. ${ }^{19}$

This study has limitations such as the establishment of diagnostic cerebral toxoplasmosis in HIV positive patients using presumptive criteria from the CDC (Centers for Disease Control and Prevention), where definitive diagnosis is that brain biopsy is still difficult .

\section{Conclusion}

There is a significant relationship between CD4 count and clinical outcomes of cerebral toxoplasmosis in HIV positive patients.

\section{Suggestion}

Secondary prevention such as CD4 testing should be done periodically every 3 months in order to detect a decrease of CD4 that can increase the risk of poor clinical outcomes.

\section{References}

[1] Damayanti, D.Penuaan Kulit dan Perawatan Kulit Dasar pada Usia Lanjut. Berkala Ilmu Kesehatan Kulit dan Kelamin. 2017 29(1)73-80

[2] Webber, T.,M., Kausch,M., Rippke, F., Schoelermann, A.,M.,and Filbary,A.,W.Treatment of Xerosis with a Topical Formulation Containing Glyceryl Glucoside, Natural Moisturizing Factors, and Ceramide. Journal of Clinical and Aesthetic Dermatology.2012.5(8):29-39

[3] Rawlings AV, Harding CR. Moisturization and skin barrier function. Dermatol Ther. 2004;17(1 suppl):43-48.

[4] Darlenski,R., Kazandjieva,K., and Tsankov, N. Skin Barrier Function: Morphological Basis And Regulatory Mechanisms. J Clin Med. 2011; 4(1):36-45

[5] Jungersted JM, Hellgren LI, Jemec GB, Agner T. Lipids and skin barrier function - a clinical perspective. Contact Dermatitis. 2008;58(5):255-262.

[6] Pappas,A. Epidermal surface lipids. Journal Dermato-Endocrinology. 2009; 1 (2):72-76

[7] Bonté F. Skin moisturization mechanisms: new data. Ann Pharm Fr. 2011;69(3):135-141.

[8] Shafiee MA, Akbarian F, Memon KK, Aarabi M, Boroumand B. Dermatologic Manifestations in Endstage Renal Disease. Iranian Journal of Kidney Diseases. 2015; 9(5): 339-353.

[9] Lupi O, Ludimila R, Mariane Z, Marlene S, Silveira CB, Sepulcri MA, et al. Cutaneous manifestations in end-stage renal disease. An. Bras. Dermatol. 2011; 86(2): 1-6.

[10] Vasantha L. Labile collagen content in the skin in kwashiorkor. Clin Chim Acta Int J Clin Chem. 1969; 26: 277-280.

[11] Vasantha L, Srikantia SG, Gopalan C. Biochemical changes in the skin in kwashiorkor. Am J Clin Nutr. 1970; 23: 78-82.

[12] Iabichella ML, Fusari V, Largo P, Pediliggieri C, Sawadogo E, Izzo A, et al. A Case of Skin Ulcer in Severe Acute Malnutrition Treated with Hyperoil@. Austin J Clin Case Rep. 2017; 4(1): 111. 


\section{International Journal of Research SCIEnCE \& MANagement}

[13]Ramarajan, M.,Rukmini,M.,S.,Sulekha, S.,Anupama,H.,Poornima, M. Typical dermatosis in kwashiorkor. Asian Journal of Pharmaceutical and Clinical Research. 2017.10(8):1-3

[14] Martin, G.,C., and Pencharz, P.,B. Sulfur Amino Acids Metabolism From Protein Synthesis of Gluthatione. Chapter 19.in: Dardevet, D. The Molecular Nutrition Of Amino Acids And Proteins. 2016. Elsevier;London:pp 265-282

[15] Jahoor F. Effects of decreased availability of sulfur amino acids in severe childhood undernutrition. Nutr Rev. 2012; 70: 176-187

[16] Jahoor F, Badaloo A, Reid M, Forrester T. Protein metabolism in severe childhood malnutrition. Ann Trop Paediatr. 2012; 28: 87-101.

[17] Park TH, Park CH, Ha SK. Dry skin (xerosis) in patients undergoing maintenance haemodialysis: the role of decreased sweating of the eccrine sweat gland. Nephrol Dial Transplant. 1995; 10(12): 2269.

[18] Mirza,R., Wahid, Z., and Talat, H. Dermatological Manifestations in Chronic Renal Failure Patients on Haemodialysis. JLUMHS . 2012;11(1):24-28

[19] Tjiptaningrum A, Hartanto BA. Dampak Proteinuria pada Anak. Majority. 2016; 5(2): 22-26.

[20] Nilawati GA. Profil sindrom nefrotik pada ruang perawatan anak. Sari Pediatri. 2012; 14, (4): $269-272$.

[21] Kharisma, Y. Tinjauan UmumPenyakit Sindrom Nefrotik. Repository UNISBA. Bandung :Fakultas Kedokteran UNISBA. 2017.Hal:1-26

[22] Davison AM, Cameron JS, Grunfeld JP, Ponticelli C, Ritz E, Winearls CG, et al. Oxford textbook of clinical nephrology. 5rd ed. New York: Oxford university Press. 2015.

[23] Cattran DC, Cook HT, Fervenza FC, Floege J, Gipson DS, Glassock RJ, et al. Kidney Disease : Improving Global Outcomes (KDIGO) Clinical Practice Guideline for Glomerulonephritis. Kidney Int. 2012; 2: 139-274. Barco D, Giménez-Arnau A. Xerosis: a Dysfunction of the Epidermal Barrier. Actas Dermosifiliografica. 2008 : 99(9): 671-682.

[24] Akarsu,S., Ozbagcivan,O., Ilknur, I., Semiz,F., Inci,B., and Fetil,E.Xerosis cutis and associated cofactors in women with prurigo nodularis. An Bras Dermatol. 2018;93(5):671-9.

[25] Baumann L. Dry Skin. In: Cosmetic Dermatology. Principles and Practice. Mc Graw Hill: New York. 2009: 29-32

[26]Rose, L.,H., Tod, B.,Joseph, C.,Aimee, G.,Karen.Text and Atlas of Wound Diagnosis and Treatment.Second Edition.Chapter 1.McGraw Hill:New York.2015

[27] Ersch J, Stallmach T. Assessing gestational age from histology of fetal skin: an autopsy study of 379 fetuses. Obstet Gynecol. 1999; 94:753-757.

[28] Satish L, Kathju S. Cellular and Molecular Characteristics of Scarless versus Fibrotic Wound Healing. Dermatol Res Pract. 2010:790234. 2010.

[29] Nikolovski J, Stamatas GN, Kollias N, et al. Barrier function and water holding and transport properties of infant stratum corneum are different from adult and continue to develop through the first year of life. J Invest Dermatol. 2008; 128:1728-1736.

[30] Tagami H. Location-related differences in structure and function of the stratum corneum with special emphasis on those of the facial skin. Int J Cosmet Sci. 2008; 30:413-434.

[31] Coolen NA, Schouten KC, Boekema BK, et al. Wound healing in a fetal, adult, and scar tissue model: a comparative study. Wound Repair Regen. 2010; 18:291-301.

[32] Coolen NA, Schouten KC, Middelkoop E, et al. Comparison between human fetal and adult skin. Arch Dermatol Res. 2010; 302:47-55.

[33] Visscher MO, Utturkar R, Pickens WL, et al. Neonatal skin maturation--vernix caseosa and free amino acids. Pediatr Dermatol. 2011; 28:122-132. 